\title{
University spillovers, absorptive capacities, and firm performance
}

\section{Erik E. Lehmann ${ }^{1} \cdot$ Matthias Menter $^{2}$ D $\cdot$ Katharine Wirsching ${ }^{1}$}

Received: 6 July 2021 / Revised: 15 December 2021 / Accepted: 30 December 2021 /

Published online: 3 March 2022

(c) The Author(s) 2022

\begin{abstract}
This study investigates the impact of both university spillovers and firms' absorptive capacities on firms' financial performance, using a multilevel approach. Considering internal firm characteristics as well as external regional characteristics, our results clearly show that university spillovers do not have a per se stimulating effect. It is the interaction between firms' absorptive capacities and local university spillovers, which proves to have a positive and significant effect on firms' economic performance. We further find that there is an optimal level of absorptive capacities, implying that 'a more the better' logic does not apply. Our findings give impetus to a call for more comprehensive public policy strategies. Policy makers have to balance the support provided to knowledge producing regional actors such as universities as well as knowledge exploiting actors such as knowledge-based firms to leverage local resources and ultimately create economic value within regional innovation systems by enabling efficient technology transfer processes.
\end{abstract}

Keywords Regional innovation systems $\cdot$ Absorptive capacity $\cdot$ Knowledge spillover · University spillover · Technology transfer $\cdot$ Firm performance

JEL Classification $\mathrm{O} 31 \cdot \mathrm{O} 32 \cdot \mathrm{O} 38$

Matthias Menter

matthias.menter@uni-jena.de

Erik E. Lehmann

erik.lehmann@wiwi.uni-augsburg.de

Katharine Wirsching

katharine.wirsching@wiwi.uni-augsburg.de

1 Faculty of Business and Economics, University of Augsburg, Universitaetsstr. 16, 86159 Augsburg, Germany

2 Faculty of Economics and Business Administration, Friedrich Schiller University Jena, Carl-Zeiss-Str. 3, 07743 Jena, Germany 


\section{Introduction}

Local factors and resources constitute essential determinants of a firm's choice of location. As Audretsch (2015, p. 129) claims, "choosing the right place can bestow upon the firm access to crucial assets that can, in turn, create or enhance the competitiveness of that firm and, ultimately, its economic value". Already Porter (1990) suggested that local competitiveness also translates to the competitive advantage of a firm and German-Soto and Flores (2013, p. 2) stress that "the essence of any modern economy relies on its ability to increase the application of knowledge, which makes us think about innovation in terms of knowledge used to create new knowledge". In this respect, crucial questions arise like how more applied knowledge is generated, how this knowledge spills over and how this knowledge could be absorbed and exploited by firms to generate new knowledge, innovations, and marketable products (Leyden \& Menter, 2018). The underlying innovation mechanisms here refer to the exploitation of opportunities originating from knowledge spillovers by universities, research institutes, or overlooked and neglected by incumbent firms (Audretsch \& Keilbach, 2007; Brown, 2016; Lehmann, 2015). More precisely, firms invest in absorptive capacities to exploit the opportunities originating from knowledge spillovers, generated by external sources (Cohen \& Levinthal, 1990).

There is a convincing literature that both external factors, the spillovers and endowment of places (Audretsch \& Lehmann, 2005), as well as internal capabilities, the firms' abilities to absorb and exploit these spillovers (Escribano et al., 2009), are important drivers of firm performance and competitiveness (Grillitsch \& Nilsson, 2017; Lau \& Lo, 2015). While there is overwhelming empirical evidence confirming the importance of positive local externalities (Eriksson \& Lindgren, 2009; Hervas-Oliver et al., 2018) on the one hand and a firm's internal ability to absorb and exploit these spillovers for increased performance and competitiveness (Audretsch et al., 2019; Caiazza et al., 2015) on the other hand, the logic underlying the idea of a 'fit' is rather unexplored. Only a few studies combined the internal and external factors, as well as direct and indirect effects, to investigate drivers of incremental innovation performance (Cantner et al., 2011; Ritala \& Hurmelinna-Laukkanen, 2013; Tödtling et al., 2009). One recent exception is Tomás-Miquel et al. (2019), confirming that interorganizational ties are a moderating factor between firms' internal absorptive capacities and their incremental innovative performance. Prajogo (2016) thereby shows that certain innovation strategies and designs do fit with their environmental surrounding and harvest good performance, while others do not.

Our study follows this literature and argues that there are recognizable, understandable, and predictable relations among the environmental features and firms' choice and decision variables of strategy and organization that determine which constellations will do well and which are less likely to do so. We further argue that these mechanisms are rather complementary than linear and parallel. While each mechanism alone may affect firm performance positively, we assume that it is the complementary relationship of both that matters for firm performance 
and thus regional growth effects. We therefore conflate insights from the fields of knowledge spillover theory and absorptive capacities to investigate how the complementarity of internal assets (absorptive capacities) and external assets (knowledge spillovers) shapes firm performance.

Adopting a multilevel approach, our results suggest that firm performance is positively shaped by firms' absorptive capacities, whereas (university) knowledge spillovers do not have a per se stimulating effect. It is the interaction between firms' absorptive capacities and regional university spillovers which proves to have a positive and significant effect on firms' economic performance. We further find that there is an optimal level of absorptive capacities, implying that 'a more the better' logic does not apply. Thus, our results reinforce the absorptive capacity theory of knowledge spillover entrepreneurship in that only the co-existence of new knowledge and adequate knowledge capacities facilitate knowledge-based entrepreneurial technology transfer activities and the transformation of knowledge spillovers into economic knowledge, ultimately resulting in higher levels of firm performance. Knowledge-intensive universities thereby foster firm performance through their academic entrepreneurial orientation and their respective strive to engage in activities beyond teaching and research-given sufficient absorptive capacities of co-located firms. Local knowledge spillovers and the existence and proximity to institutions as the sources of spillovers are thus pivotal in explaining the variation in regional growth and firm performance (De Fuentes \& Dutrénit, 2013; Proeger, 2020; Simmie, 2002).

Our study adds to the literature by providing insights into the effects of regional innovation mechanisms on firm performance. The relationship between external knowledge production and internal absorption of these spillovers is obviously a high-priority issue for both, policy makers and firm managers. The public sector, i.e. research-intensive universities and associated knowledge spillovers, possesses the potential to boost the private sector, i.e. firms and associated performance, given sufficient levels of absorptive capacities (see Bishop et al., 2011). Our research fits into a growing literature examining the economic impact of distinct regional innovation mechanisms on firm level performance and associated entrepreneurial technology transfer activities of prevalent market participants (Audretsch et al., 2012; Guerrero et al., 2015; Hayter \& Link, 2015; Ugur \& Vivarelli, 2021). Policy makers need to ensure the complementarity of policy approaches that increase knowledge spillovers from universities and simultaneously strengthen firm-specific absorptive capacities to ultimately achieve the desired positive spillover-performance relationship.

By providing a holistic view on various regional innovation mechanisms and respective effects on the growth performance of firms, policy recommendations are derived which focus on two distinct dimensions: research intensive universities as strategic agents within regional innovation systems as well as knowledge-based firms, serving as the exploiter of disseminated knowledge. Public policy should not encourage public-private sector interactions and incentivize the public sector to engage in the commercialization of knowledge without considering the idiosyncratic regional prerequisites, i.e. prevalent absorptive capacities of firms (see Cunningham et al., 2019, 2021). A comprehensive policy approach is needed which creates conducive regional innovation systems and associated technology transfer processes that 
stimulate firms' abilities to recognize and exploit entrepreneurial opportunities to effectively contribute to a region's economic vitality and growth (see Stam, 2015).

The remainder of this paper is structured as follows. In the next section, we present the theoretical background and develop our hypotheses. The third section describes our dataset, provides descriptive statistics, and explains our methodological approach. Section four discusses our main findings. A final section concludes and derives policy recommendations.

\section{Theoretical background and hypotheses development}

Each region has specific assets, unique capabilities, institutions, and industrial policies that make it different from other regions (Sleuwaegen \& Boiardi, 2014). Each firm has specific assets, unique capabilities, organizational architectures, and strategies that make it different from other firms (Barney, 1991). Porter (1990) suggests that the performance of a firm is ultimately shaped by the ability of the top management to link the firm's unique assets to the spatial context. Especially knowledge has thereby been identified as the basis for competitive advantages in firms (Argote \& Ingram, 2000). Accordingly, previous research has on the one hand dealt to a large extent with the process of knowledge generation and diffusion (i.e. knowledge spillovers) and on the other hand with the utilization and exploitation of associated knowledge spillovers (i.e. knowledge absorption). This paper focuses on the combination of these two strands of literature, considering that the microeconomic local environment mediates the relationship between competition, innovation, productivity growth, and performance on the firm and regional level. ${ }^{1}$

\subsection{The knowledge spillover theory}

The knowledge spillover theory (Acs et al., 2009, 2013; Audretsch \& Lehmann, 2005; Audretsch et al., 2012) dates back at least to the early work of Marshall (1890) taking positive externalities and spillover effects of agglomeration as the starting point. Over the years, this approach has been refined and defines regional growth as an endogenous phenomenon (Krugman, 1991; Romer, 1994), where knowledge spillovers explain much of the (statistical) variation of regional innovation activities and regional growth (Griliches, 1979; Jaffe, 1989). In particular, Jaffe (1986) stimulated a new stream of research analyzing the sources of knowledge production, in particular universities and research institutes (Acs et al., 1992, 1994; Audretsch, 2014; Audretsch \& Feldman, 1996; Audretsch \& Stephan, 1996; Brown, 2016; Guerrero et al., 2015; Lehmann, 2015), emphasizing that geographic proximity to these sources of knowledge spillovers shapes location decisions (Audretsch \& Lehmann, 2005), firm performance, and local competitiveness (Anselin et al.,

\footnotetext{
${ }^{1}$ Combining the geographic dimension with the nature of innovation beyond the micro and firm level gave rise to concepts like 'regional systems of innovation' (Cooke \& Morgan, 1993; Doloreux, 2002) or 'national systems of innovation' (Acs et al., 2016; Lundvall, 2010).
} 
1997; Audretsch et al., 2005; Hall et al., 2003; Henderson et al., 1998; Mowery \& Ziedonis, 2001). The "transport" mechanism triggering geographical proximity and knowledge spillovers is the tacit component of knowledge (Kogut \& Zander, 1992). In contrast to codified knowledge, such as patents or academic articles, tacit knowledge is sticky and bound to the individual as the source of knowledge and therefore difficult to record in such a way that it is meaningful and readily understood (Teece, 2005). Ambiguities inherent in the tacitness of knowledge can thus only be overcome by face-to-face communication in the presence of intensive, trustbased personal contacts, which may be ineffective or infeasible over long distances (Teece, 1977, 1981). Jaffe (1986) thus argues that the "transport" mechanisms are mainly based on informal and personnel conversations and geographic proximity a necessary condition in capturing and exploiting the spillover benefits (Gertler, 2003; Kogut \& Zander, 1992; Polanyi, 1967).

Local universities have thus been identified as critical sources of knowledge production and knowledge spillovers whereas academic research has made different attempts to measure and capture both the quantity and quality of knowledge spillovers (see Perkmann et al. 2013 for a comprehensive survey). The quantity aspect is mostly captured by measuring the amount of money spent on R\&D, the number of employees engaged in research, the number of articles published, or the number of patents (Hall et al., 2003; Henderson et al., 1998; Varga, 2000), whereby data is publicly available through Web of Science or official statistics. The quantity effects are highly correlated with the size effects, whereby such measures are not necessarily linked to the absorption and exploitation of knowledge spillovers. Thus, more recent research is concerned about also including quality effects of academic research, like the number of citations linked to patents and articles, ranking positions of universities, faculties or academics like star scientists, and a more differentiated view of researchers, like their position in national and international research rankings, their networks, and distinguishing between general and specific knowledge and the nature of spillovers in the social sciences and the natural sciences (Audretsch et al., 2005; Graf \& Menter, 2021). Especially the understanding of the role of universities as knowledge producers and processes of formal as well as informal technology transfer to the private sector is important to emphasize the origins and sources of local knowledge spillovers (Leyden \& Menter, 2018). The impact of universities as an important source of knowledge spillovers is undisputed and the empirical evidence overwhelming. We thus follow the existing literature and posit:

Hypothesis 1 High levels of local (university) knowledge spillovers lead to a higher level of economic performance of firms.

\subsubsection{Absorptive capacities}

The production and provision of knowledge to spill over as a necessary ingredient for firm performance and local competitiveness is unquestionable (Lau \& Lo, 2015; Li et al., 2013). While knowledge from universities and other sources of production may spill over like 'manna from heaven' or is just 'in the air' (Marshall, 1890), spillovers do not necessarily lead to innovations, technologies, and marketable products. 
Unfortunately, only a few studies focus on measuring the effects of knowledge spillovers. Carlsson and Fridh (2002) state that only half of the invention disclosures in US universities result in patent applications. From these $50 \%$, only about half, $25 \%$, result in actual patents, and one third, about $16 \%$, of these patents are licensed. From these $16 \%$, only $10-20 \%$ of licenses yield a significant income. Hence, only about one percent of the invention disclosures in US universities yield in a significant income. Braunerhjelm et al. (2010, p. 107) confirm these results by stating that "only $1 \%$ or $2 \%$ of inventions are successful in reaching the market". The overwhelming part of invention disclosures, the other $98 \%$ of uncommercialized ideas, should thus rest in tacit knowledge.

One strand of the literature has identified new venture creation and entrepreneurship on the local level as a mechanism to pass the knowledge filter by filtering out the most promising ideas overlooked by others and to transform them into marketable products (Acs et al., 2014, 2016; Audretsch et al., 2016; Fritsch, 2013). There exists considerable empirical evidence confirming that knowledge spillovers and new venture creation play a fundamental role in forwarding innovations (Audretsch, 2014; Brown, 2016; Guerrero et al., 2015; Lehmann \& Menter, 2018; Teece \& Linden, 2017). New venture creation captures only a fraction of the knowledge that spills over, and although entrepreneurial firms play an important role in the regional ecosystem, incumbent firms are the backbone of the national and regional economy. ${ }^{2}$

While the entrepreneurship literature has focused on the filtering mechanisms linking new venture creation to knowledge spillovers, a parallel strand of literature has emerged, linking knowledge spillovers to incumbent firms. Cohen and Levinthal (1989) provide a compelling interpretation of this link. They argue that by developing the capacity to adapt new technologies and ideas developed by universities and firms, firm-specific investments in knowledge such as R\&D provide the capacity to absorb external knowledge. Consequently, incumbent firms should develop the absorptive capacity by $R \& D$ investments to appropriate at least some of the knowledge that spills over from external sources (Catozzella \& Vivarelli, 2014). The more firms invest in R\&D activities, the more knowledge is produced, leading to both, an increase of the absorptive capacity as well as the total pool of tacit and hitherto unexplored knowledge that could be then exploited and transformed into economic knowledge. The internal endowment of resources and capacities has since then widely been considered as a strategic source of performance, made popular by the so-called resource-based view of the firm (Barney, 1991). Among these resources, absorptive capacities have been identified as one of the most significant notions to emerge in organizational and management research in recent decades (Audretsch et al., 2021b; Lane \& Lubatkin, 1998; Lane et al., 2006; Zahra \& George, 2002) to explain firm incremental innovations and

\footnotetext{
${ }^{2}$ Delgado et al. (2020) investigate the servicification of the US economy using a longitudinal approach and find that the transformation of incumbent manufacturing firms leads to job growth. Sanders et al. (2020) give an excellent overview of the German economy rooted in the so-called 'Mittelstand' and its importance, suggesting to encourage more entrepreneurship.
} 
performance (Ritala \& Hurmelinna-Laukkanen, 2013; Rodrigo-Alarcón et al., 2020; Tomás-Miquel et al., 2019; Tödtling et al., 2009; Zahra \& George, 2002).

The concept of absorptive capacities describes the ability to "recognize the value of new, external information, assimilate it, and apply it to commercial ends" (Cohen \& Levinthal, 1990, p. 128). The recognition and judgement of opportunities, the ability to evaluate and utilize external knowledge, are characteristics of entrepreneurial firms. But also established firms have to manage innovations as well as the utilization of ideas and access to external and internal sources of knowledge, given sufficient absorptive capacities (Cohen \& Levinthal, 1990; Guerrero et al., 2016; Qian \& Acs, 2013). In particular, for high technology and knowledge-intensive industries, the in-depth understanding of state-of-the-art techniques and updated knowledge is central to value external developments and innovations. Focusing on individuals, learning is cumulative and results are the best if there is a relation between new and consisting knowledge (Cohen \& Levinthal, 1990).

The importance of the absorptive capacity model is undisputed and provides robust results and stylized facts on the national (Qian \& Acs, 2013), regional (Fritsch \& Medrano Echalar, 2015; Lau \& Lo, 2015; Miguélez \& Moreno, 2015; Mukherji \& Silberman, 2013) or firm level (Kostopoulos et al., 2011; Moilanen et al., 2014; Wales et al., 2013; Zahra \& Hayton, 2008) and seems to be robust and independent from the national context. Cozza and Zanfei (2016) investigate the R\&D activities as a proxy for absorptive capacities of Italian companies, Bishop et al. (2011) examine data from a survey of UK firms, Kostopoulos et al. (2011) for a sample of Greek firms, Moilanen et al. (2014) focus on SMEs in less developed and peripheral regions in the North of Norway, or Miguélez and Moreno (2015) analyze a sample of 274 regions of 27 European countries, all confirming that the quality of collaborations to universities as well as geographical proximity between partners influence different capabilities that foster absorptive capacities.

As the adaption of new technologies and ideas is a key factor for innovation and renewal and thus essential for the long-term survival of firms, it is obvious that also firm performance is influenced by absorptive capacities. In conclusion, we follow previous research that the access and utilization of external ideas and sources of knowledge is shaped by firms' absorptive capacities (Cohen \& Levinthal, 1990; Qian \& Acs, 2013). To measure the impact of absorptive capacities, we include firm performance as a relevant output.

Hypothesis 2 High levels of absorptive capacities within firms lead to a higher level of economic performance of firms.

Previous research suggests that a possible partial substitution effect between internal R\&D efforts and external knowledge activities exists (Escribano et al., 2009; Tomás-Miquel et al., 2019), leading to a reduction in (incremental) firm performance. Such reductions can be produced because of the effects of higher motivation and coordination costs induced by competing teams and tasks 
(Minbaeva et al., 2003; Pitt \& Clarke, 1999) and a costly excessive oversizing in absorptive capacity (Tomás-Miquel et al., 2019). Todorova and Durisin (2007) reorganize a new model based on a critical reflection of the central ideas on absorptive capacities by Cohen and Levinthal (1990) and Zahra and George (2002), taking circumstances into account that can be hindrance. Especially the ability to value new external knowledge is crucial for further steps in the overall transformation process and should be considered, if research detangles the concept of absorptive capacities. At the same time, it is precisely on this point that there is a risk of overinvestment, as it is extremely difficult to learn or improve the ability to value new knowledge.

Additionally, the contingent factors have a crucial influence on a successful transformation. Especially in incumbent firms, social integration mechanisms as well as power relations play an important role when it comes to leveraging capabilities in organizations. The relationships with customers, but also commitments to other stakeholders can prevent a proper valuation and exploitation of new knowledge (Hill \& Rothaermel, 2003). Activities of managers as internal stakeholders as well as suppliers and customers as external stakeholders and their influence through power can result in substitution and crowding out effects (Hagedoorn \& Wang, 2012). Consequently, social integration mechanisms as well as power relations influence the whole process of building absorptive capacities and can have a negative effect on the economic performance of firms. According to the weak-tie theory of Granovetter (1973), especially relationships that are distant, unsteady, and thus weak are beneficial when new knowledge should be absorbed. All these effects indicate that there is an optimum for investing in absorptive capacities, leading us to posit an inverted U-shaped relationship between absorptive capacities and firm performance:

Hypothesis 3 Absorptive capacities follow a quadratic (inverted U-shaped) relation with economic performance of firms.

\subsubsection{Joint effects of knowledge spillovers and absorptive capacity}

Despite the potential partial effects of the link between absorptive capacities and knowledge spillovers on firm performance, diverse effects may occur because of the interaction between both levels. First, absorptive capacities and knowledge spillovers are not (mathematically) linked together, both variables are selected independently from each other to shape performance positively, like parallels, without an intersection. Both, R\&D management in firms and higher education and cluster policy, are chosen independently. For the empirical testing, we would also abstract from the so-called 'Demsetz-Hypotheses' that policy makers and top managers are fully rational and statistically insignificant results reflect that all decisions are made optimally (Demsetz, 1973). Instead, we follow the overwhelming and convincing literature emphasizing the importance of firms having absorptive capacities as an essential pre-condition for translating knowledge spillovers into new technologies and products, the research question being not whether but how both variables are linked together. 
The first approach, dating back to the early post-war period (Leyden \& Menter, 2018), took the so-called 'linear model of innovation' as a starting point. In this framework, a linear unidirectional relationship is drawn running from basic research and knowledge spillovers and innovation to the ultimate goal of economic performance and economic growth (Balconi et al., 2010; Leyden \& Menter, 2018). This approach has been refined and amended including feedback relationships and contextual influences, and greatly benefited from the micro econometric work of Griliches (1979), Jaffe (1989), as well as Audretsch and Feldman (1996).

This literature, that empirically tested the link between knowledge production and performance, generated a series of econometrically robust results substantiating the view that firms' investment in knowledge inputs in the form of R\&D expenditures were required to produce innovative output (Cohen \& Klepper, 1992a, 1992b; Griliches, 1984). Firm performance in this framework follows a linear relationship with absorptive capacity, usually measured by $R \& D$ expenditures, and local knowledge spillovers, most often measured by patents or publication numbers of universities at the regional level (Audretsch \& Feldman, 1996; Jaffe et al., 1993). An increase in the decision variable, either knowledge spillovers or absorptive capacity, would lead to a linear increase in the output variable. The 'knowledge production function' made popular by Griliches (1979) has become the most popular approach to measure the effect and performance of both the production of knowledge and the absorption capacity of firms. In this regard, several authors have proposed a direct, linear, and positive association between the regional innovation systems and the existence of knowledge spillovers, and innovation and firm performance (Bell, 2005; Coombs et al., 2009; Pellegrino \& Piva, 2020). Fritsch and Slavtchev (2011, p. 914) examine the efficiency of different factors in regional innovation systems and find that "knowledge spillovers within the private sector as well as those that occur between public research institutions (universities as well as non-university research institutes) and actors in the private sector have a positive impact on private sector innovation activity", especially when the technical fields of research in public research institutes match the innovation efforts in the private sector. The authors find that a higher R\&D intensity in firms stimulates knowledge spillovers. Additionally, the intensity of university- industry linkages, measured as third-party funding, is beneficial for regional innovation systems and regional wealth (Lehmann, \& Menter, 2016). Summing up, it is the combination of knowledge spillovers and absorptive capacities that positively affects firm performance. We express these arguments in a more formal way by positing:

Hypothesis 4 The effect of local (university) knowledge spillovers on firm performance is positively moderated by firms' absorptive capacities.

\section{Dataset and methodology}

\subsection{Dataset}

Our primary goal is to analyze the dependency of firm performance on internal firm characteristics as well as on external regional characteristics. As we specifically 
want to investigate the interdependency of firms' absorptive capacities and local (university) knowledge spillovers, our dataset consists of 450 German knowledgeintensive publicly listed and traded firms. We deliberately focus on knowledge-based firms as only high technology industries are influenced by potential university spillovers (Audretsch \& Keilbach, 2007). We capture firm performance by firms' operating income, firms' absorptive capacities by firms' R\&D spending, and the existence of local (university) knowledge spillovers by universities' level of income resulting from third-party funding activities (see Table 1).

We follow existing studies focusing on absorptive capacities [see Lane et al. (2006) for an overview of absorptive capacity papers] and measure firms' absorptive capacities by their investment in new knowledge, enabling them to reduce their respective knowledge filter. Universities increasingly serve as regional knowledge factories, thus enable firms to absorb and exploit respective knowledge spillovers (Anselin et al., 1997; Audretsch \& Lehmann, 2005). By taking the engagement of universities in third-party funding activities ${ }^{3}$ (e.g. grants, donations, contract research, etc.) as a proxy for the existence of local knowledge flows, we refer to Audretsch and Keilbach (2007) who link investments in new knowledge to an enhanced level of knowledge spillovers. We rely on data provided by the German Federal Statistical Office, the German Patent and Trademark Office as well as the Thomson Datastream to further include regional characteristics such as the regional industry competition (measured by the number of filed patents within a region per workforce), regional vitality, i.e. regional economic performance (measured by gross domestic product per capita), regional density (measured by the number of citizens per square kilometer of land area), and universities' technical orientation (measured by universities being labeled as 'technical universities') as well as universities' size (measured by university students) within a 15-year period from 1998 to 2012. As firm performance is also shaped by efficient internal processes, i.e. its process capital (Scafarto et al., 2016), we control for firms' asset utilization (measured by firms' asset turnover ratio) as well as for firms' size (measured by the number of employees). We further control for industry and time effects.

\subsection{Descriptive statistics}

Our sample includes 450 publicly listed and traded firms located in Germany operating in knowledge-intensive industries. The large spread of our utilized variables might thereby be best explained by Fritsch and Slavtchev (2011) who examine regional innovation systems in Germany and show that considerable differences among German regions exist (see Table 2). Consequently, our dataset captures regions with both high and low innovative and economic output. Not only the regions but also the respective firms in our sample vary significantly, which is reflected by the share of small and medium sized enterprises as well as large firms,

\footnotetext{
3 Third-party funds are funds in addition to the regular university budget (basic funding) from public or private sources. Third-party funds can be granted to the university itself, to faculties, departments, and institutes, or to individual scientists.
} 


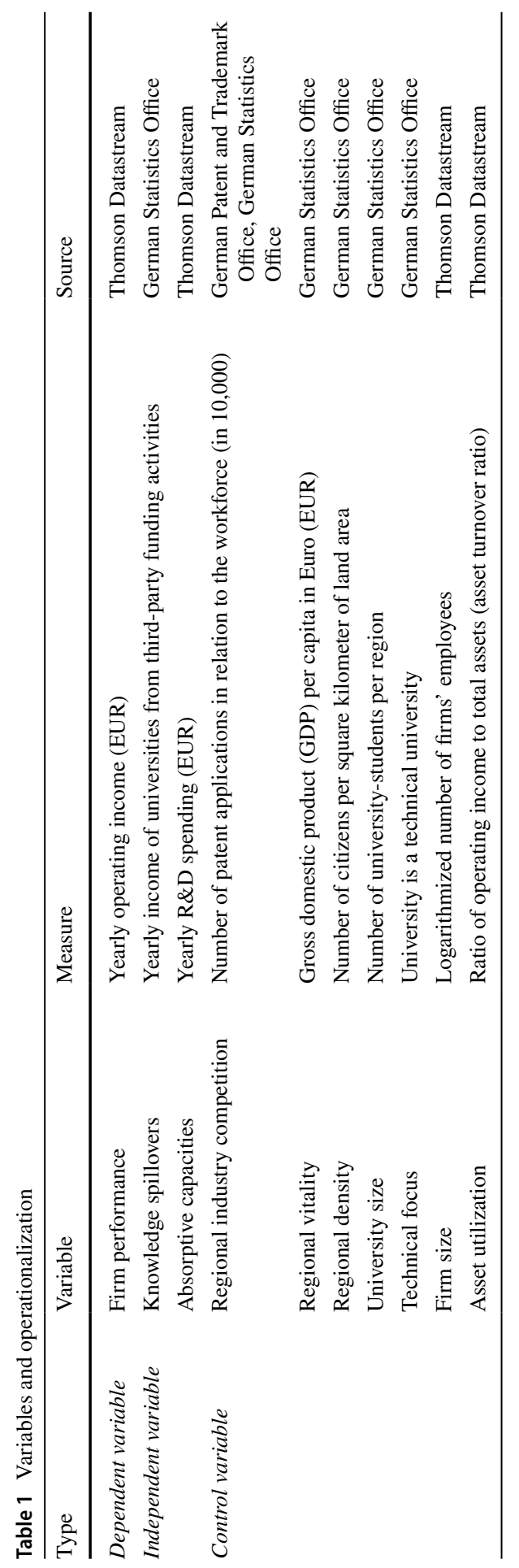


Table 2 Descriptive statistics

\begin{tabular}{llllll}
\hline Variable & Mean & Std. dev & Min & Max & Observations \\
\hline Firm performance & 168,103 & 799,406 & $-5,605,000$ & $10,800,000$ & $\mathrm{~N}=5360$ \\
Absorptive capacities & 147,404 & 603,524 & 0 & $6,900,000$ & $\mathrm{~N}=3502$ \\
Knowledge spillovers & 81,202 & 102,091 & 0 & 972,242 & $\mathrm{~N}=6750$ \\
Regional industry competition & 18.64 & 16.50 & 0 & 188.99 & $\mathrm{~N}=6750$ \\
Regional vitality & 32,040 & 7720 & 14,621 & 49,358 & $\mathrm{~N}=6748$ \\
Regional density & 461.60 & 336.93 & 49.28 & 1716 & $\mathrm{~N}=6748$ \\
University size & 35,785 & 28,908 & 0 & 108,585 & $\mathrm{~N}=6750$ \\
Technical focus & 0.33 & 0.47 & 0 & 1 & $\mathrm{~N}=6750$ \\
Firm size (abs.) & 12,850 & 46,931 & 1 & 536,350 & $\mathrm{~N}=5730$ \\
Asset utilization & -0.01 & 0.45 & -25.82 & 8.24 & $\mathrm{~N}=5353$ \\
\hline
\end{tabular}

firms investing considerable amounts of money in R\&D as well as firms basing their innovative activities solely on outsourced $R \& D$ and knowledge spillovers. Although literature suggests that research intensive universities and departments influence a firm's location decision (see Audretsch et al., 2005), not all firms are co-located to universities, resulting in large differences concerning the existence of local knowledge spillovers originating from universities. In their study of motives to patent, Blind et al. (2006) show that company size matters. Due to the large differences in firm size within our sample and in order to stabilize and smooth heterogeneous variances, we transform our variable firm size, i.e. the number of firms' employees, by taking the natural logarithm.

The correlation matrix offers further insights into the bivariate correlations between internal and external firm characteristics and firm performance (see Table 3). Whereas firm performance is highly correlated with firms' absorptive capacities $(r=0.58)$, the bivariate correlations between firm performance and knowledge spillovers $(r=0.06)$, regional economic performance $(r=0.10)$ or regional innovative performance $(r=0.05)$ are rather low. Nevertheless, regional economic performance and regional innovative performance show high bivariate correlations $(r=0.52)$. Firm size is further highly correlated with firm performance $(r=0.41)$ as well as firms' investments in R\&D, i.e. their absorptive capacities $(r=0.46)$. Hence, whereas internal firm characteristics seem to influence and shape firm performance, external regional characteristics do not seem to per se influence firm performance.

\subsection{Methodology and estimation techniques}

Based on our panel data, the most straightforward method to investigate the impact of internal and external characteristics on firm performance is to employ a multilevel approach (Goldstein, 2011; Srholec, 2010). Whereas internal characteristics, i.e. firm data, can be assigned to the micro level of our dataset, external characteristics, i.e. regional data, can be assigned to the macro level of our dataset. Thus, we apply a 2-level hierarchical model which takes both the micro as well as the macro level into account (Bryk \& Raudenbush, 1992). Beyond the existence of more 


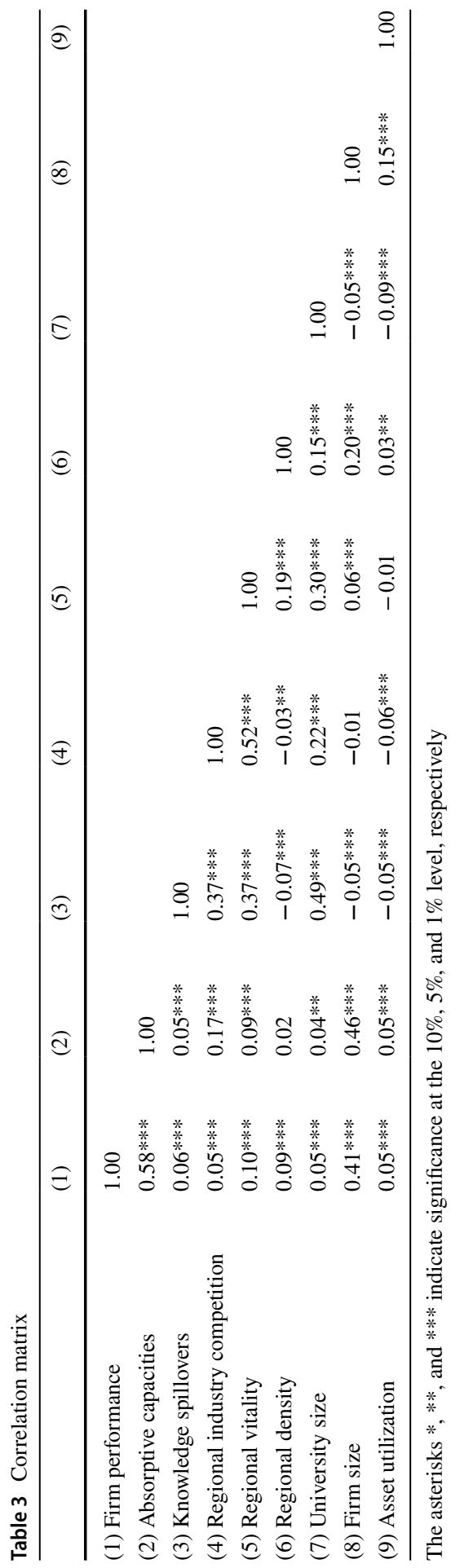


than one level of investigation, a basic prerequisite to employ multilevel models is that the dependent variable is at the lowest level of analysis (Snijders, 2011). This requirement is fulfilled, as firm performance can be assigned to the firm/micro level, i.e. our lowest level of investigation. We thereby use the following estimation:

$$
\begin{gathered}
Y_{i j t}=\beta_{0 j t}+\beta_{1} \text { frm }_{i j t-1}+\varepsilon_{i j} \\
\beta_{0 j t}=\gamma_{00 t}+\gamma_{01 t} \text { university }_{j t-1}+\gamma_{02 t} \text { region }_{j t-1}+\mu_{0 j}
\end{gathered}
$$

where $Y_{i j t}$ is firm performance, measured by the operating income, of firm $i$ in region $j$ at time $t$. Vector firm represents our first main independent variables, i.e. absorptive capacities, as well as firm specifics like firm size and firms' asset utilization. Vector university represents our second main independent variables, i.e. local knowledge spillovers, as well as university characteristics, i.e. university size and focus. Vector region finally captures our set of control variables, i.e. the regional economic and innovative performance, and regional density. As usual, $\varepsilon$ and $\mu$ represent the error terms.

To empirically test our hypotheses, our empirical approach captures linear effects, curvilinear effects, represented by the squared variable absorptive capacity that describes a potential U-shaped relationship between absorptive capacities and firm performance, as well as linear moderating effects, i.e. two-way interactions between absorptive capacities and local knowledge spillovers. As our sample only represents an excerpt of the total population of high technology firms in Germany and the inference should focus on the total population, we deliberately use randomeffects models (Bell \& Jones, 2015). A Hausman test confirms the appropriateness of our approach (Hausman, 1978). We lag all independent and control variables by one year to control for reverse causality. As shown by our descriptive statistics, the knowledge-intensive firms included in our sample are located in regions with both low as well as high levels of local (university) knowledge spillovers and economic output. Hence, endogeneity (firms may choose to locate in more innovative regions and perform higher levels of $\mathrm{R} \& \mathrm{D}$, thus gaining greater absorptive capacity, to benefit from spillovers) is rather unlikely to affect our results. To investigate isolated as well as comprehensive effects, we employ four different estimation specifications within our approach. The distinct models differ according to the set of variables included in the described vectors. The first estimation (Model I) represents our basic regression, examining the relationship between firm performance and absorptive capacities as well as the existence of local knowledge spillovers while controlling for regional and firm specifics. We continuously extend this model by including additional curvilinear effects (Model II) and linear moderating effects (Model III). Model IV represents our full model.

Although studies show that (university) knowledge spillovers are spatially limited (Audretsch, \& Feldman, 1996; Audretsch, \& Lehmann, 2005), it is possible that regional knowledge spillovers originating from a university affect the performance of a firm located in an adjacent region. The same may apply for some of our control variables, e.g. regional competition and regional vitality. This fact is likely to give rise to spatial autocorrelation (Anselin, 2001). Following Baptista and Mendonça 
(2010) and in line with Fritsch and Falck (2007), we control for possible spatial autocorrelation. We therefore apply a spatial cross-regressive model to account for the effects of the adjacent region and unobserved heterogeneity across regions. We thereby include a dummy variable for the different regions. This approach shall serve as a robustness test.

\section{Results and discussion}

The results of our estimation approach are depicted in Table 4. Model I investigates the influence of conducive regional endowments that allow knowledge spillovers on firms' economic performance and reveals an insignificant effect of local knowledge spillovers on firm performance. All further model specifications reinforce the insignificant effect of the existence of knowledge spillovers on firm performance, resulting in a rejection of hypothesis 1 . We consequently cannot confirm previous findings in that firms which engage in R\&D outsourcing activities by relying on knowledge spillovers per se benefit from being located in dynamic environments (Gilley \& Rasheed, 2000). However, sufficient regional factors and resources, i.e. adequate levels of human capital, suppliers, and customers, may enhance firm performance as indicated by the positive and significant variable regional vitality. The results further show that the existence of high competition within innovative industries, as indicated by our variable regional industry competition capturing the innovative capacity of a region, has a negative and significant effect on firm performance. We thus contribute to the ongoing discussion on whether competition helps or hinders performance (Slater \& Narver, 1994). Our results suggest that especially in high technology industries, competitive pressure undermines technological innovation and technology transfer processes. The technical orientation of a university as well as the number of students do not seem to significantly influence firm performance.

In addition to the impact of external regional characteristics, Model I as well as all other model specifications further reveal a significant and positive effect of R\&D expenditures, our proxy for firms' absorptive capacities, i.e. internal firm characteristics, on firms' financial performance. We can consequently confirm hypothesis 2 in that the existence of absorptive capacities within firms leads to a higher level of economic performance of firms. We thereby reinforce previous findings which found that firms with higher R\&D expenditures and thus enhanced technological innovation capabilities experience superior financial performance (Camisón \& VillarLópez, 2014; Sher \& Yang, 2005). We can also confirm previous results in that the influence of firm size on firm performance is positive and significant as indicated by the variable firm size (Lee, 2009). Finally, we are able to shed light on the impact of firms' asset utilization on firm performance (Cheng et al., 2010). We find a positive yet insignificant relationship between firms' process capital, i.e. the efficiency with which a firm is deploying its assets in generating income, and firm performance.

The investigation of our hypothesized curvilinear effect reveals a negative and significant coefficient, suggesting that the relationship between absorptive capacities and firm performance follows an inverted U-shaped relationship. We can thus confirm hypothesis 3 in that an optimal level of absorptive capacities exists, reflecting 


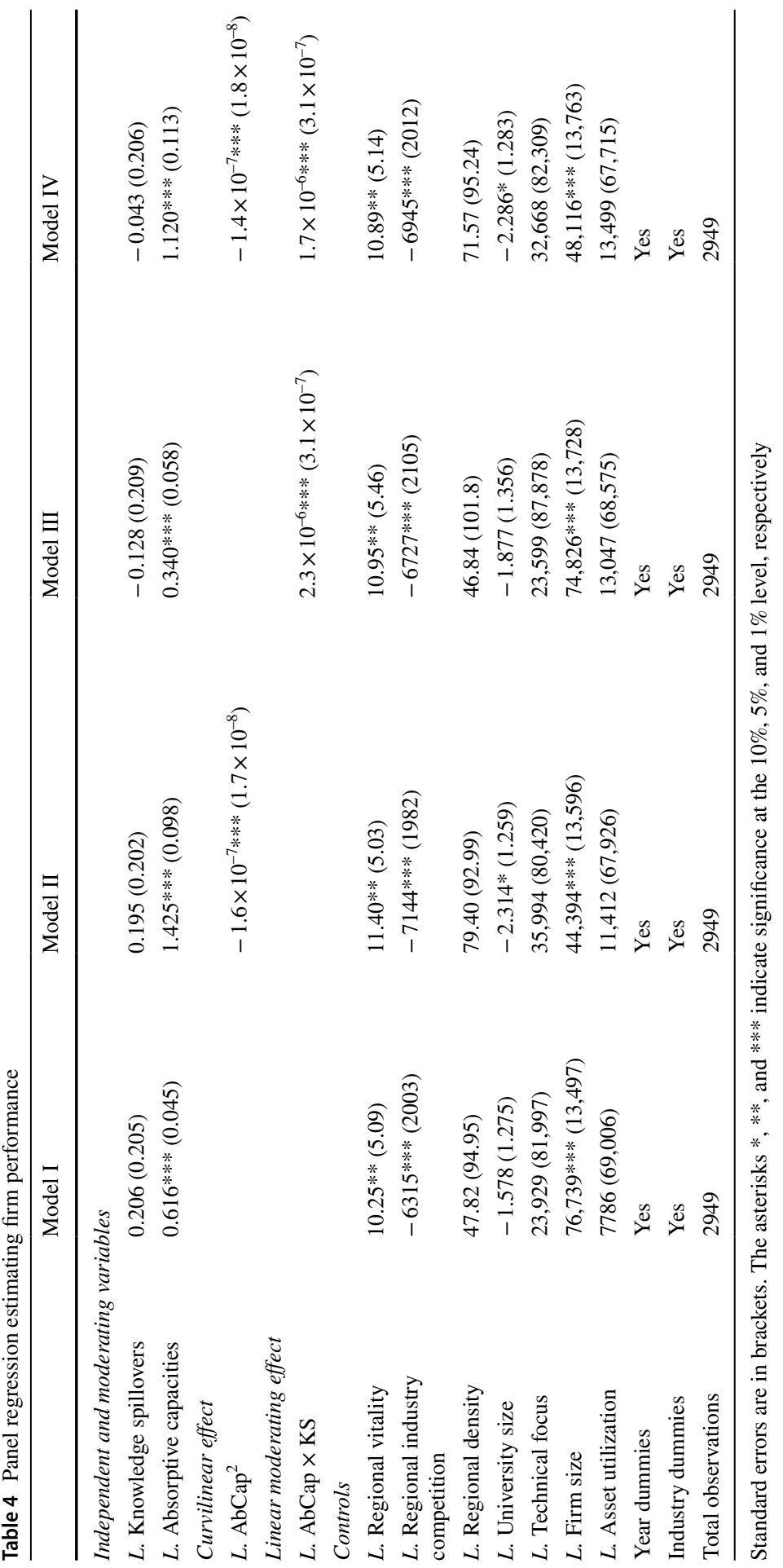


the diminishing marginal returns of additional investments in R\&D. The evaluation of our fourth hypothesis is based on the interaction between firms' absorptive capacities and prevalent local knowledge spillovers. Model III reveals a positive and significant coefficient of the interaction between internal firm characteristics and external regional characteristics. External knowledge spillovers may complement internal $\mathrm{R} \& \mathrm{D}$ activities and in turn may lead to an enhanced economic performance. We can consequently confirm hypothesis 4 in that a complementary effect between local knowledge spillovers in regions and firms' absorptive capacities leads to a higher level of economic performance of firms, hence confirm the results of previous studies focusing on R\&D spillover effects and R\&D cooperation (Belderbos et al., 2004; Chen et al., 2013). We thus reinforce the absorptive capacity theory of knowledge spillover entrepreneurship (Qian \& Acs, 2013). Knowledge-based entrepreneurial technology transfer activities and the transformation of knowledge spillovers into economic knowledge are based on the co-existence of new knowledge and adequate knowledge capacities, ultimately resulting in higher levels of firm performance. Model IV constitutes our full model and confirms all postulated relationships. Our spatial cross-regressive models confirm the robustness of our results (see Table 5).

As with all research, our study is subject to a number of limitations. Measuring the existence of knowledge spillovers by focusing on knowledge provided by the public sector does not capture the total amount of potential local knowledge flows. Also, private sector research activities lead to knowledge spillovers, so-called R\&D spillover effects, which should ideally be considered as well. We further base our multilevel approach on a rather small unbalanced panel which is not ideal as larger sample sizes could substantiate recommendations derived from our results. Additionally, further control variables could be included within the analyses, e.g. university-firm collaborations as well as firm-firm collaborations to differentiate distinct types of knowledge spillovers and examine their individual impact on firm performance.

\section{Conclusion}

The importance of context has been the focus of many research efforts over the recent years (Audretsch et al., 2021a; Autio et al., 2014; De Clercq et al., 2013). As the creation, recognition, absorption, and exploitation of new knowledge is highly context dependent, scholars have investigated the impact of distinct context dimensions (organizational, institutional, industry, social, political) and have set up various frameworks such as the regional innovation system framework to capture the influencing factors on entrepreneurial innovation, technology transfer, and performance. Wirth and Markard (2011, p. 637) note that "different context structures do not only influence whether a novel technological field develops quickly or fails but they also shape the direction of development". Adding characteristics beyond internal capabilities to the knowledge production and knowledge exploitation function has resulted in a wealth of studies focusing on the existence and geographic constraints of local knowledge spillovers and their impact on firm location and performance (Audretsch et al., 2005; Calcagnini et al., 2016; Grillitsch \& Nilsson, 2017; Singh 


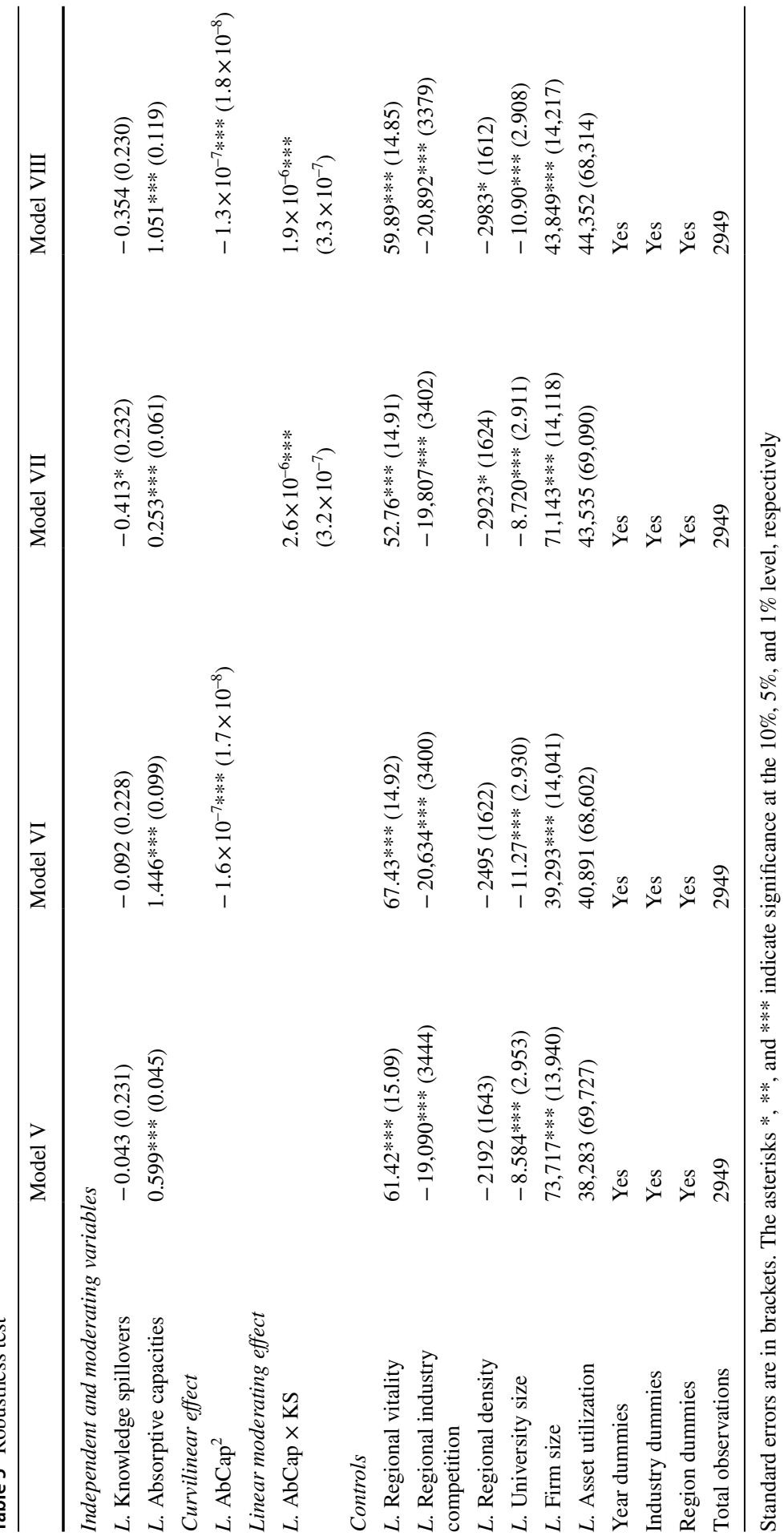


\& Marx, 2013). The underlying knowledge spillover theory of entrepreneurship has reinforced respective research agendas as it suggests that higher knowledge contexts induce more entrepreneurial opportunities, thus greater potential to innovate, enhancing firms' competitive positioning within the market (Audretsch \& Keilbach, 2007). Increased firm performance yet not only depends on higher knowledge contexts, but also on firms' absorptive capacities allowing firms to understand, recognize, and commercialize new knowledge. The absorptive capacity theory of knowledge spillover entrepreneurship has identified human capital as the critical driver for knowledge-based entrepreneurial activities (Qian \& Acs, 2013). Taking a firm perspective, human or corporate capital can be nurtured and shaped by firms' financial investments in understanding and creating new knowledge and technologies, i.e. spending money on professional development and R\&D.

\subsection{Managerial implications}

This study has taken investments of knowledge-intensive publicly listed and traded firms in corporate capital, i.e. investments in $R \& D$, as a starting point and has investigated the influence of the co-existence of both higher knowledge contexts and firms' absorptive capacities on firm performance. Our results reveal that the existence of local (university) knowledge spillovers does not have a per se positive impact on firm performance. It is the co-existence of adequate absorptive capacities and high levels of (university) knowledge spillovers which enables firms to benefit from local knowledge flows, thus penetrate the knowledge filter. Managers whose companies are expected to benefit from knowledge spillovers are advised to invest in their human capital and develop their absorptive capabilities in this way. We can further show that the relationship between firm performance and absorptive capacities follows an inverted U-shape, implying that 'a more the better' logic does not apply. Therefore, decision-makers should carefully consider which type of investment contributes to the company's success and to what extent. Beyond (university) knowledge spillovers, both internal firm characteristics such as size as well as external regional characteristics such as regional economic vitality further shape firm performance. Contributing to an ongoing discussion whether local competition helps or hinders firm performance, this study finds evidence that within knowledge-intensive high technology industries, high levels of competition rather counteract augmented firm performance.

\subsection{Policy implications}

Beyond implications for knowledge-intensive firms to not only base their location decisions on higher knowledge contexts, but also on their inherent capacities to absorb and exploit local knowledge spillovers, our findings might also provide an impetus to reconsider current public policy strategies. Much research effort has been devoted to guiding policy makers how to enhance the efficiency and effectiveness of public sector organizations within regional innovation systems, enabling especially public research organizations such as universities to produce more knowledge, 
thus supply the private sector with additional knowledge inputs through technology transfer (Cunningham et al., 2019, 2021). Our results clearly show that this policy approach is by far not sufficient and only one side of the coin. Idiosyncratic regional prerequisites, i.e. prevalent absorptive capacities of firms, have to be considered by policy makers, in order to achieve the ultimate goal of public policy: regional economic prosperity.

Consequently, a comprehensive policy approach is needed which balances the support provided to knowledge producing regional actors such as universities as well as knowledge exploiting actors such as knowledge-based firms. Economic growth is not based on new knowledge but on the exploitation thereof, yet requiring sufficient regional absorptive capacities. Thus, our study shows that the traditional technology transfer model is insufficient, as it does not capture the context of knowledge production and exploitation, hence oversimplifies the complexity of respective processes. Scholars like Stam (2015) have already provided more comprehensive frameworks which emphasize the importance of the entrepreneurial context.

\subsection{Implications for future research}

Future research should deliberately examine the effects of more comprehensive public policy approaches encouraging public-private sector interactions by taking both the local knowledge context as well as firms' capabilities to exploit respective opportunities into account. One-size-fits-all policy approaches are unlikely to be successful, as "contexts will always matter and need to be appreciated for determining the most relevant accent at every stage of the process" (Stam \& Bosma, 2015, p. 297). Therefore, more nuanced models of technology transfer need to be conceptualized which take respective fuzzy processes and their actual contexts into consideration. We thus reinforce the call of Bradley et al. (2013) for alternative views of technology transfer for public-private sector interactions.

Funding Open Access funding enabled and organized by Projekt DEAL.

Open Access This article is licensed under a Creative Commons Attribution 4.0 International License, which permits use, sharing, adaptation, distribution and reproduction in any medium or format, as long as you give appropriate credit to the original author(s) and the source, provide a link to the Creative Commons licence, and indicate if changes were made. The images or other third party material in this article are included in the article's Creative Commons licence, unless indicated otherwise in a credit line to the material. If material is not included in the article's Creative Commons licence and your intended use is not permitted by statutory regulation or exceeds the permitted use, you will need to obtain permission directly from the copyright holder. To view a copy of this licence, visit http://creativecommons.org/licen ses/by/4.0/.

\section{References}

Acs, Z. J., Audretsch, D. B., \& Feldman, M. P. (1992). Real effects of academic research: Comment. The American Economic Review, 82(1), 363-367. 
Acs, Z. J., Audretsch, D. B., \& Feldman, M. P. (1994). R\&D spillovers and recipient firm size. The Review of Economics and Statistics, 76(2), 336-340.

Acs, Z. J., Audretsch, D. B., \& Lehmann, E. E. (2013). The knowledge spillover theory of entrepreneurship. Small Business Economics, 41(4), 757-774.

Acs, Z. J., Audretsch, D. B., Lehmann, E. E., \& Licht, G. (2016). National systems of innovation. The Journal of Technology Transfer, 42(5), 997-1008.

Acs, Z. J., Autio, E., \& Szerb, L. (2014). National systems of entrepreneurship: Measurement issues and policy implications. Research Policy, 43(3), 476-494.

Acs, Z. J., Braunerhjelm, P., Audretsch, D. B., \& Carlsson, B. (2009). The knowledge spillover theory of entrepreneurship. Small Business Economics, 32(1), 15-30.

Anselin, L. (2001). Spatial econometrics. In B. H. Baltagi (Ed.), A companion to theoretical econometrics (pp. 310-330). Blackwell Publishing.

Anselin, L., Varga, A., \& Acs, Z. (1997). Local geographic spillovers between university research and high technology innovations. Journal of Urban Economics, 42(3), 422-448.

Argote, L., \& Ingram, P. (2000). Knowledge transfer: A basis for competitive advantage in firms. Organizational Behavior and Human Decision Processes, 82(1), 150-169.

Audretsch, D. B. (2014). From the entrepreneurial university to the university for the entrepreneurial society. The Journal of Technology Transfer, 39(3), 313-321.

Audretsch, D. B. (2015). Everything in its place: Entrepreneurship and the strategic management of cities, regions, and states. Oxford University Press.

Audretsch, D. B., Belitski, M., Caiazza, R., Günther, C., \& Menter, M. (2021a). From latent to emergent entrepreneurship: The importance of context. Technological Forecasting and Social Change. https://doi.org/10.1016/j.techfore.2021.121356

Audretsch, D. B., \& Feldman, M. P. (1996). R\&D spillovers and the geography of innovation and production. The American Economic Review, 86(3), 630-640.

Audretsch, D. B., Hülsbeck, M., \& Lehmann, E. E. (2012). Regional competitiveness, university spillovers, and entrepreneurial activity. Small Business Economics, 39(3), 587-601.

Audretsch, D. B., \& Keilbach, M. (2007). The theory of knowledge spillover entrepreneurship. Journal of Management Studies, 44(7), 1242-1254.

Audretsch, D. B., \& Lehmann, E. E. (2005). Does the knowledge spillover theory of entrepreneurship hold for regions? Research Policy, 34(8), 1191-1202.

Audretsch, D. B., Lehmann, E., \& Menter, M. (2016). Public cluster policy and new venture creation. Journal of Industrial and Business Economics, 43(3), 357-381.

Audretsch, D. B., Lehmann, E. E., Menter, M., \& Seitz, N. (2019). Public cluster policy and firm performance: Evaluating spillover effects across industries. Entrepreneurship and Regional Development, 31(1-2), 150-165.

Audretsch, D. B., Lehmann, E. E., Menter, M., \& Wirsching, K. (2021b). Intrapreneurship and absorptive capacities: The dynamic effect of labor mobility. Technovation, 99, 102129. https://doi.org/10. 1016/j.technovation.2020.102129

Audretsch, D. B., Lehmann, E. E., \& Warning, S. (2005). University spillovers and new firm location. Research Policy, 34(7), 1113-1122.

Audretsch, D. B., \& Stephan, P. E. (1996). Company-scientist locational links: The case of biotechnology. The American Economic Review, 86(3), 641-652.

Autio, E., Kenney, M., Mustar, P., Siegel, D., \& Wright, M. (2014). Entrepreneurial innovation: The importance of context. Research Policy, 43(7), 1097-1108.

Balconi, M., Brusoni, S., \& Orsenigo, L. (2010). In defence of the linear model: An essay. Research Policy, 39(1), 1-13.

Baptista, R., \& Mendonça, J. (2010). Proximity to knowledge sources and the location of knowledgebased start-ups. The Annals of Regional Science, 45(1), 5-29.

Barney, J. (1991). Firm resources and sustained competitive advantage. Journal of Management, 17(1), 99-120.

Belderbos, R., Carree, M., \& Lokshin, B. (2004). Cooperative R\&D and firm performance. Research Policy, 33(10), 1477-1492.

Bell, A., \& Jones, K. (2015). Explaining fixed effects: Random effects modeling of time-series crosssectional and panel data. Political Science Research and Methods, 3(1), 133-153.

Bell, G. G. (2005). Clusters, networks, and firm innovativeness. Strategic Management Journal, 26(3), 287-295. 
Bishop, K., D’Este, P., \& Neely, A. (2011). Gaining from interactions with universities: Multiple methods for nurturing absorptive capacity. Research Policy, 40(1), 30-40.

Blind, K., Edler, J., Frietsch, R., \& Schmoch, U. (2006). Motives to patent: Empirical evidence from Germany. Research Policy, 35(5), 655-672.

Bradley, S. R., Hayter, C. S., \& Link, A. (2013). Models and methods of university technology transfer. Foundations and Trends in Entrepreneurship, 9(6), 571-650.

Braunerhjelm, P., Acs, Z. J., Audretsch, D. B., \& Carlsson, B. (2010). The missing link: Knowledge diffusion and entrepreneurship in endogenous growth. Small Business Economics, 34(2), 105-125.

Brown, R. (2016). Mission impossible? Entrepreneurial universities and peripheral regional innovation systems. Industry and Innovation, 23(2), 189-205.

Bryk, A. S., \& Raudenbush, S. W. (1992). Hierarchical linear models: Applications and data analysis methods. Sage Publications.

Caiazza, R., Richardson, A., \& Audretsch, D. (2015). Knowledge effects on competitiveness: From firms to regional advantage. The Journal of Technology Transfer, 40(6), 899-909.

Calcagnini, G., Favaretto, I., Giombini, G., Perugini, F., \& Rombaldoni, R. (2016). The role of universities in the location of innovative start-ups. The Journal of Technology Transfer, 41(4), 670-693.

Camisón, C., \& Villar-López, A. (2014). Organizational innovation as an enabler of technological innovation capabilities and firm performance. Journal of Business Research, 67(1), 2891-2902.

Cantner, U., Joel, K., \& Schmidt, T. (2011). The effects of knowledge management on innovative success-An empirical analysis of German firms. Research Policy, 40(10), 1453-1462.

Carlsson, B., \& Fridh, A. C. (2002). Technology transfer in United States universities. Journal of Evolutionary Economics, 12(1), 199-232.

Catozzella, A., \& Vivarelli, M. (2014). Beyond absorptive capacity: In-house R\&D as a driver of innovative complementarities. Applied Economics Letters, 21(1), 39-42.

Chen, S.-S., Chen, Y.-S., Liang, W.-L., \& Wang, Y. (2013). R\&D spillover effects and firm performance following R\&D increases. Journal of Financial and Quantitative Analysis, 48(5), 1607-1634.

Cheng, M.-Y., Lin, J.-Y., Hsiao, T.-Y., \& Lin, T. W. (2010). Invested resource, competitive intellectual capital, and corporate performance. Journal of Intellectual Capital, 11(4), 433-450.

Cohen, W. M., \& Klepper, S. (1992a). The anatomy of industry R\&D intensity distributions. The American Economic Review, 82(4), 773-799.

Cohen, W. M., \& Klepper, S. (1992b). The tradeoff between firm size and diversity in the pursuit of technological progress. Small Business Economics, 4(1), 1-14.

Cohen, W. M., \& Levinthal, D. A. (1989). Innovation and learning: The two faces of R\&D. The Economic Journal, 99(397), 569-596.

Cohen, W. M., \& Levinthal, D. A. (1990). Absorptive capacity: A new perspective on learning and innovation. Administrative Science Quarterly, 35(1), 128-152.

Cooke, P., \& Morgan, K. (1993). The network paradigm: New departures in corporate and regional development. Environment and Planning D: Society and Space, 11(5), 543-564.

Coombs, J. E., Deeds, D. L., \& Duane Ireland, R. (2009). Placing the choice between exploration and exploitation in context: A study of geography and new product development. Strategic Entrepreneurship Journal, 3(3), 261-279.

Cozza, C., \& Zanfei, A. (2016). Firm heterogeneity, absorptive capacity and technical linkages with external parties in Italy. The Journal of Technology Transfer, 41(4), 872-890.

Cunningham, J. A., Lehmann, E. E., Menter, M., \& Seitz, N. (2019). The impact of university focused technology transfer policies on regional innovation and entrepreneurship. The Journal of Technology Transfer, 44(5), 1451-1475.

Cunningham, J. A., Lehmann, E. E., Menter, M., \& Seitz, N. (2021). Regional innovation, entrepreneurship and the reform of the Professor's privilege in Germany. In M. Guerrero \& D. Urbano (Eds.), Technology transfer and entrepreneurial innovations (pp. 175-205). Springer.

De Clercq, D., Lim, D. S., \& Oh, C. H. (2013). Individual-level resources and new business activity: The contingent role of institutional context. Entrepreneurship Theory and Practice, 37(2), 303-330.

De Fuentes, C., \& Dutrénit, G. (2013). SMEs' absorptive capacities and large firms' knowledge spillovers: Micro evidence from the machining industry in Mexico. Institutions and Economies, 5(1), $1-30$.

Delgado, M., Kim, J. D., \& Mills, K. (2020). The servicification of the US economy: The role of startups versus incumbent firms. In M. J. Andrews, A. Chatterji, J. Lerner, \& S. Stern (Eds.), The role of innovation and entrepreneurship in economic growth. Chicago: University of Chicago Press. 
Demsetz, H. (1973). Industry structure, market rivalry, and public policy. The Journal of Law and Economics, 16(1), 1-9.

Doloreux, D. (2002). What we should know about regional systems of innovation. Technology in Society, 24(3), 243-263.

Eriksson, R., \& Lindgren, U. (2009). Localized mobility clusters: Impacts of labour market externalities on firm performance. Journal of Economic Geography, 9(1), 33-53.

Escribano, A., Fosfuri, A., \& Tribó, J. A. (2009). Managing external knowledge flows: The moderating role of absorptive capacity. Research Policy, 38(1), 96-105.

Fritsch, M. (2013). New business formation and regional development: A survey and assessment of the evidence. Foundations and Trends in Entrepreneurship, 9(3), 249-364.

Fritsch, M., \& Falck, O. (2007). New firm formation by industry over space and time: A multi-level analysis. Regional Studies, 41, 157-172.

Fritsch, M., \& Medrano Echalar, L. F. (2015). New technology in the region-agglomeration and absorptive capacity effects on laser technology research in West Germany, 1960-2005. Economics of Innovation and New Technology, 24(1-2), 65-94.

Fritsch, M., \& Slavtchev, V. (2011). Determinants of the efficiency of regional innovation systems. Regional Studies, 45(7), 905-918.

German-Soto, V., \& Flores, L. G. (2013). Assessing some determinants of the regional patenting: An essay from the Mexican States. Technology and Investment, 4(3), 1-9.

Gertler, M. S. (2003). Tacit knowledge and the economic geography of context, or the undefinable tacitness of being (there). Journal of Economic Geography, 3(1), 75-99.

Gilley, K. M., \& Rasheed, A. (2000). Making more by doing less: An analysis of outsourcing and its effects on firm performance. Journal of Management, 26(4), 763-790.

Goldstein, H. (2011). Multilevel statistical models (Vol. 922). John Wiley \& Sons.

Graf, H., \& Menter, M. (2021). Public research and the quality of inventions: The role and impact of entrepreneurial universities and regional network embeddedness. Small Business Economics. https://doi.org/10.1007/s11187-021-00465-w

Granovetter, M. S. (1973). The strength of weak ties. American Journal of Sociology, 78(6), 1360-1380.

Griliches, Z. (1979). Issues in assessing the contribution of research and development to. Bell Journal of Economics, 10, 92-116.

Griliches, Z. (1984). Market value, R\&D, and patents. R\&amp;D, patents, and productivity (pp. 249252). University of Chicago Press.

Grillitsch, M., \& Nilsson, M. (2017). Firm performance in the periphery: On the relation between firminternal knowledge and local knowledge spillovers. Regional Studies, 51(8), 1219-1231.

Guerrero, M., Cunningham, J. A., \& Urbano, D. (2015). Economic impact of entrepreneurial universities' activities: An exploratory study of the United Kingdom. Research Policy, 44(3), 748-764.

Guerrero, M., Urbano, D., Fayolle, A., Klofsten, M., \& Mian, S. (2016). Entrepreneurial universities: Emerging models in the new social and economic landscape. Small Business Economics, 47(3), $551-563$.

Hagedoorn, J., \& Wang, N. (2012). Is there complementarity or substitutability between internal and external R\&D strategies? Research Policy, 41(6), 1072-1083.

Hall, B. H., Link, A. N., \& Scott, J. T. (2003). Universities as research partners. Review of Economics and Statistics, 85(2), 485-491.

Hausman, J. A. (1978). Specification tests in econometrics. Econometrica, 46, 1251-1271.

Hayter, C. S., \& Link, A. N. (2015). On the economic impact of university proof of concept centers. The Journal of Technology Transfer, 40(1), 178-183.

Henderson, R., Jaffe, A. B., \& Trajtenberg, M. (1998). Universities as a source of commercial technology: A detailed analysis of university patenting, 1965-1988. Review of Economics and Statistics, 80(1), 119-127.

Hervas-Oliver, J. L., Sempere-Ripoll, F., Rojas Alvarado, R., \& Estelles-Miguel, S. (2018). Agglomerations and firm performance: Who benefits and how much? Regional Studies, 52(3), 338-349.

Hill, C. W., \& Rothaermel, F. T. (2003). The performance of incumbent firms in the face of radical technological innovation. Academy of Management Review, 28(2), 257-274.

Jaffe, A. B. (1986). Technological opportunity and spillovers of R\&D: Evidence from firms' patents, profits and market value. The American Economic Review, 76(5), 984-1001.

Jaffe, A. B. (1989). Real effects of academic research. The American Economic Review, 79(5), 957-970.

Jaffe, A. B., Trajtenberg, M., \& Henderson, R. (1993). Geographic localization of knowledge spillovers as evidenced by patent citations. The Quarterly Journal of Economics, 108(3), 577-598. 
Kogut, B., \& Zander, U. (1992). Knowledge of the firm, combinative capabilities, and the replication of technology. Organization Science, 3(3), 383-397.

Kostopoulos, K., Papalexandris, A., Papachroni, M., \& Ioannou, G. (2011). Absorptive capacity, innovation, and financial performance. Journal of Business Research, 64(12), 1335-1343.

Krugman, P. (1991). Increasing returns and economic geography. Journal of Political Economy, 99(3), 483-499.

Lane, P. J., Koka, B. R., \& Pathak, S. (2006). The reification of absorptive capacity: A critical review and rejuvenation of the construct. Academy of Management Review, 31(4), 833-863.

Lane, P. J., \& Lubatkin, M. (1998). Relative absorptive capacity and interorganizational learning. Strategic Management Journal, 19(5), 461-477.

Lau, A. K., \& Lo, W. (2015). Regional innovation system, absorptive capacity and innovation performance: An empirical study. Technological Forecasting and Social Change, 92, 99-114.

Lee, J. (2009). Does size matter in firm performance? Evidence from US public firms. International Journal of the Economics of Business, 16(2), 189-203.

Lehmann, E. E. (2015). The role of universities in local and regional competitiveness. In D. B. Audretsch, A. N. Link, \& M. L. Walshok (Eds.), The Oxford handbook of local competitiveness (pp. 211-236). Oxford University Press.

Lehmann, E. E., \& Menter, M. (2016). University-industry collaboration and regional wealth. The Journal of Technology Transfer, 41(6), 1284-1307.

Lehmann, E. E., \& Menter, M. (2018). Public cluster policy and neighboring regions: Beggar-thy-neighbor? Economics of Innovation and New Technology, 27(5-6), 420-437.

Leyden, D. P., \& Menter, M. (2018). The legacy and promise of Vannevar Bush: Rethinking the model of innovation and the role of public policy. Economics of Innovation and New Technology, 27(3), 225-242.

Li, W., Veliyath, R., \& Tan, J. (2013). Network characteristics and firm performance: An examination of the relationships in the context of a cluster. Journal of Small Business Management, 51(1), 1-22.

Lundvall, B. - $\AA$. (2010). National systems of innovation: Toward a theory of innovation and interactive learning. Anthem Press.

Marshall, A. (1890). Principles of economics (1920th ed.). Macmillan.

Miguélez, E., \& Moreno, R. (2015). Knowledge flows and the absorptive capacity of regions. Research Policy, 44(4), 833-848.

Minbaeva, D., Pedersen, T., Björkman, I., Fey, C. F., \& Park, H. J. (2003). MNC knowledge transfer, subsidiary absorptive capacity, and HRM. Journal of International Business Studies, 34(6), 586-599.

Moilanen, M., Østbye, S., \& Woll, K. (2014). Non-R\&D SMEs: External knowledge, absorptive capacity and product innovation. Small Business Economics, 43(2), 447-462.

Mowery, D. C., \& Ziedonis, A. A. (2001). The geographic reach of market and non-market channels of technology transfer: comparing citations and licenses of university patents (No. w8568). National Bureau of Economic Research.

Mukherji, N., \& Silberman, J. (2013). Absorptive capacity, knowledge flows, and innovation in US metropolitan areas. Journal of Regional Science, 53(3), 392-417.

Pellegrino, G., \& Piva, M. (2020). Innovation, industry and firm age: Are there new knowledge production functions? Eurasian Business Review, 10, 65-69.

Perkmann, M., Tartari, V., McKelvey, M., Autio, E., Broström, A., D’Este, P., Fini, R., Geuna, A., Grimaldi, R., Hughes, A., Krabel, S., Kitson, M., Llerena, P., Lissoni, F., Salter, A., \& Sobrero, M. (2013). Academic engagement and commercialisation: A review of the literature on universityindustry relations. Research Policy, 42(2), 423-442.

Pitt, M., \& Clarke, K. (1999). Competing on competence: A knowledge perspective on the management of strategic innovation. Technology Analysis and Strategic Management, 11(3), 301-316.

Polanyi, M. (1967). Sense-giving and sense-reading. Philosophy, 42(162), 301-325.

Porter, M. E. (1990). The competitive advantage of nations. Harvard Business Review, 68(2), 73-93.

Prajogo, D. I. (2016). The strategic fit between innovation strategies and business environment in delivering business performance. International Journal of Production Economics, 171(2), 241-249.

Proeger, T. (2020). Knowledge spillovers and absorptive capacity-Institutional evidence from the "German Mittelstand.” Journal of the Knowledge Economy, 11(1), 211-238.

Qian, H., \& Acs, Z. J. (2013). An absorptive capacity theory of knowledge spillover entrepreneurship. Small Business Economics, 40(2), 185-197. 
Ritala, P., \& Hurmelinna-Laukkanen, P. (2013). Incremental and radical innovation in coopetition-The role of absorptive capacity and appropriability. Journal of Product Innovation Management, 30(1), 154-169.

Rodrigo-Alarcón, J., Parra-Requena, G., \& Ruiz-Ortega, M. J. (2020). Cognitive social capital and absorptive capacity as antecedents of entrepreneurial orientation: A configurational approach. Eurasian Business Review, 10, 493-517.

Romer, P. M. (1994). The origins of endogenous growth. Journal of Economic Perspectives, 8(1), 3-22.

Sanders, M., Stenkula, M., Fritsch, M., Herrmann, A. M., Latifi, G., Páger, B., Wyrwich, M., et al. (2020). A reform strategy for Germany. In M. Sanders, A. Marx, \& M. Stenkula (Eds.), The entrepreneurial society (pp. 163-202). Springer.

Scafarto, V., Ricci, F., \& Scafarto, F. (2016). Intellectual capital and firm performance in the global agribusiness industry: The moderating role of human capital. Journal of Intellectual Capital, 17(3), $530-552$.

Sher, P. J., \& Yang, P. Y. (2005). The effects of innovative capabilities and R\&D clustering on firm performance: The evidence of Taiwan's semiconductor industry. Technovation, 25(1), 33-43.

Simmie, J. (2002). Knowledge spillovers and reasons for the concentration of innovative SMEs. Urban Studies, 39(5-6), 885-902.

Singh, J., \& Marx, M. (2013). Geographic constraints on knowledge spillovers: Political borders vs. spatial proximity. Management Science, 59(9), 2056-2078.

Slater, S. F., \& Narver, J. C. (1994). Does competitive environment moderate the market orientation-performance relationship? The Journal of Marketing, 58, 46-55.

Sleuwaegen, L., \& Boiardi, P. (2014). Creativity and regional innovation: Evidence from EU regions. Research Policy, 43(9), 1508-1522.

Snijders, T. A. (2011). Multilevel analysis. Springer.

Srholec, M. (2010). A multilevel approach to geography of innovation. Regional Studies, 44(9), 1207-1220.

Stam, E. (2015). Entrepreneurial ecosystems and regional policy: A sympathetic critique. European Planning Studies, 23(9), 1759-1769.

Stam, E., \& Bosma, N. (2015). Local policies for high-growth firms. In D. B. Audretsch, A. N. Link, \& M. L. Walshok (Eds.), The Oxford handbook of local competitiveness (pp. 286-305). Oxford University Press.

Teece, D. J. (1977). Technology transfer by multinational firms: The resource cost of transferring technological know-how. The Economic Journal, 87(346), 242-261.

Teece, D. J. (1981). The market for know-how and the efficient international transfer of technology. The Annals of the American Academy of Political and Social Science, 458(1), 81-96.

Teece, D. J. (2005). Technological know-how, property rights, and enterprise boundaries: The contribution of Arora and Merges. Industrial and Corporate Change, 14(6), 1237-1240.

Teece, D. J., \& Linden, G. (2017). Business models, value capture, and the digital enterprise. Journal of Organization Design, 6(1), 1-14.

Todorova, G., \& Durisin, B. (2007). Absorptive capacity: Valuing a reconceptualization. Academy of Management Review, 32(3), 774-786.

Tödtling, F., Lehner, P., \& Kaufmann, A. (2009). Do different types of innovation rely on specific kinds of knowledge interactions? Technovation, 29(1), 59-71.

Tomás-Miquel, J. V., Molina-Morales, F. X., \& Expósito-Langa, M. (2019). Loving outside the neighborhood: The conflicting effects of external linkages on incremental innovation in clusters. Journal of Small Business Management, 57(4), 1738-1756.

Ugur, M., \& Vivarelli, M. (2021). Innovation, firm survival and productivity: The state of the art. Economics of Innovation and New Technology, 30(5), 433-467.

Varga, A. (2000). Local academic knowledge transfers and the concentration of economic activity. Journal of Regional Science, 40(2), 289-309.

Wales, W. J., Parida, V., \& Patel, P. C. (2013). Too much of a good thing? Absorptive capacity, firm performance, and the moderating role of entrepreneurial orientation. Strategic Management Journal, 34(5), 622-633.

Wirth, S., \& Markard, J. (2011). Context matters: How existing sectors and competing technologies affect the prospects of the Swiss Bio-SNG innovation system. Technological Forecasting and Social Change, 78(4), 635-649.

Zahra, S. A., \& George, G. (2002). Absorptive capacity: A review, reconceptualization, and extension. Academy of Management Review, 27(2), 185-203. 
Zahra, S. A., \& Hayton, J. C. (2008). The effect of international venturing on firm performance: The moderating influence of absorptive capacity. Journal of Business Venturing, 23(2), 195-220.

Publisher's Note Springer Nature remains neutral with regard to jurisdictional claims in published maps and institutional affiliations. 